\title{
SPEECH AUDIOMETRY: NONSENSE MONOSYLLABIC LISTS IN MODERN GREEK
}

\author{
Nikolaos Trimmis ${ }^{1}$, Georgios Vrettakos ${ }^{1}$, Panagiota Gouma ${ }^{2}$, Theodoros Papadas ${ }^{3}$ \\ ${ }^{1}$ Technological Educational Institute of Patras, Greece \\ ${ }^{2}$ University of Thessaly, Greece \\ ${ }^{3}$ University Hospital of Patras, Greece
}

Corresponding author: Nikolaos Trimmis, 1 M. Alexandrou str, Koukouli, GR26334, Patra, Greece, e-mail: trimmis@teipat.gr

\begin{abstract}
Background: The purpose of the present study was to develop a nonsense suprathreshold speech audiometry test for native speakers of Modern Greek. The specific aims were to construct phonemically balanced lists of nonsense monosyllables and to perform a preliminary investigation of list equivalence.
\end{abstract}

Material and Methods: Nonsense monosyllables with possible CV, VC, and CVC phonemic combinations in Greek were chosen as stimuli. To examine list equivalency, the final recorded lists were administered monaurally in $5 \mathrm{~dB}$ increments to 40 adults (20 males and 20 females) whose hearing was within normal limits.

Results: A nonsense monosyllabic speech audiometry test for speakers of Modern Greek has been developed. The test material consists of two lists, each of which contains 50 open-set monosyllabic combinations. The lists satisfied the criteria of equal phonemic balance, composition of Modern Greek speech, phonemic differentiation, and equal average difficulty. Statistical analysis of the results revealed no statistical significant differences among the lists at the 0.05 level.

Conclusions: These findings suggest that the test is a useful tool for clinical purposes.

Key Words: nonsense • speech audiometry • suprathreshold • phonemic balance

\section{AUDIOMETRÍA DEL HABLA: LISTAS DE MONOSÍLABOS SIN SENTIDO EN GRIEGO MODERNO}

Abstracto

Antecedentes: El objetivo del presente estudio fue desarrollar una prueba de audiometría de reconocimiento supraumbral del habla sin sentido para los hablantes nativos de griego moderno. Los objetivos específicos fueron construir listas fonémicamente equilibradas de monosílabos sin sentido y llevar a cabo una investigación preliminar de equivalencia de las listas.

Material y Métodos: Como estímulos se eligieron monosílabos sin sentido con posibles combinaciones fonémicas de CV, VC y CVC en griego. Para examinar la equivalencia de las listas, las listas definitivas registradas fueron administradas de modo monaural en incrementos de $5 \mathrm{~dB}$ a 40 adultos (20 hombres y 20 mujeres) cuya audiencia estaba dentro de los límites normales.

Resultados: Se ha desarrollado una prueba de audiometría basada en monosílabos sin sentido para los hablantes de griego moderno. El material de prueba consta de dos listas, cada una de las cuales contiene 50 combinaciones monosilábicas. Las listas cumplen los criterios del equilibrio fonémico igual, la composición del habla en griego moderno, la diferenciación fonémica y dificultad media igual. El análisis estadístico de los resultados no reveló diferencias estadísticamente significativas entre las listas en el nivel de 0,05 .

Conclusión: Estos resultados sugieren que la prueba es una herramienta útil para fines clínicos.

Palabras claves: sin sentido • audiometría del habla $\bullet$ supraumbral • balance fonémica 


\title{
РЕЧЕВАЯ АУДИОМЕТРИЯ: БЕССМЫСЛЕННЫЕ ОДНОСЛОЖНЫЕ СПИСКИ В СОВРЕМЕННОМ ГРЕЧЕСКОМ ЯЗЫКЕ
}

\begin{abstract}
Резюме
Предпосылки: Цель этой исследовательской работы - это проведение теста по бессмысленной надпороговой речевой аудиометрии на носителях греческого языка. Специальные задачи - создать фонематически гармоничные списки бессмысленных слогов, а также провести предварительное исследование равнозначности списков.
\end{abstract}

Материалы и Методы: В качестве стимулов выбраны бессмысленные слоги с возможными фонематическими $\mathrm{CV}, \mathrm{VC}$, и CVC структурами на греческом языке. Чтобы проверить равнозначность списков, для 40 взрослых (20 мужчин и 20 женщин) с нормальным слухом были монаурально представлены последние записанные списки при повышении интенсивности на 5 дБ.

Результаты: Проведен аудиометрический речевой односложный тест на носителях современного греческого языка. Материал теста состоял из двух списков, каждый из которых содержал 50 односложных сочетаний открытого состава. Списки соответствуют критериям одинакового фонематического равновесия, построения современного греческого языка, фонематической дифференциации и одинаковой средней сложности. Статистический анализ результатов не открыл никаких статистических значительных разниц среди списков на уровне 0.05 .

Заключение: Полученные данные показывают, что тест это полезный для клинических результатов инструмент.

Ключевые слова: бессмысленный • речевая аудиометрия • надпороговый • фонематическое равновесие

\section{Background}

The benefits of speech audiometry are well documented and have made speech audiometry a standard part of a complete diagnostic evaluation of hearing disorders, hearing aid fitting, and aural rehabilitation for almost all audiologists (Martin et al., 1994). It provides more information regarding a person's hearing impairment than pure-tone audiometry alone. The audiogram provides a general description of the magnitude of a person's hearing loss; however, it does not always adequately portray the communication difficulties an individual may experience or the person's aural rehabilitation needs.

There are two fundamental speech diagnostic tools used routinely in a complete audiological evaluation (CAE): speech recognition threshold (SRT) testing and word recognition score (WRS) testing. The purpose of SRT testing is to find the lowest level of hearing for speech at which $50 \%$ of the speech material is correctly recognised. The purpose of WRS testing is to determine the approximate suprathreshold level at which an individual can correctly understand and repeat a list of words (ASHA, 1988).

Although various speech materials are used to obtain each of these measurements with maximum accuracy, today most SRTs and WRSs are obtained with the use of spondaic and monosyllabic words respectively. However, testing materials differ among languages because of differences in phonetic, syntactic, and semantic rules (Carhart, 1951). For instance, an inadequate number of monosyllables with semantic content exist in the Modern Greek language. Therefore, bisyllables are used for WRS testing (Trimmis et al., 2006; Iliadou et al., 2006).

Other types of speech materials used primarily in aural rehabilitation applications and research are nonsense syllables that have been used as a means of assessing a patient's ability to discriminate between phonemes of spoken language (Brad, 2010). These nonsense syllable tests are probably the most sensitive approach for examining the details of a patient's speech recognition difficulties because of the sensitivity to minimal hearing loss (Gelfand, 2001). Their lack of intelligibility increase the difficulty of the task to the listener (Martin, 1997). Also, nonsense monosyllables are appropriate for amplification assessment and aural rehabilitation treatment programs, since they permit a detailed analysis of the phonemic errors made by the listener. They have the advantage that each phoneme can be scored individually, which is important in hearing aid assessment and rehabilitation. In addition, they ensure that vocabulary and memory effects are reduced (Martin, 1997; Gelfand, 2001). The City University of New York Nonsense Syllable Test (CUNY-NST) (Resnick, et al., 1975; Levitt \& Resnick, 1978), the Nonsense Syllable Test (NST) (Edgerton \& Danhauer, 1979), and the ORCA Nonsense Syllable Test (Kuk et al., 2010) are three carefully developed and widely known tests of this type.

In Greece, speech audiometry is becoming an established clinical procedure due to the development of new tests (Trimmis et al., 2006; Iliadou et al., 2006; Trimmis et al., 2007; Trimmis et al., 2008). Thrasyvoulou \& Marinakis (2010) applied the new WRS tests (Trimmis et al., 2006; Iliadou et al., 2006) on 125 patients with different types and degrees of hearing loss. They reported that speech tests played an important role in differential diagnosis. However, speech audiometry has not been used in the areas of hearing aid fitting and aural rehabilitation due to the limited number of materials. No studies are available on this subject. Recently, Trimmis et al. (2009) developed a nonsense bisyllable test of speech sound discrimination consisting of 5 lists with $50 \mathrm{CVCV}$ bisyllables in each list without semantic content in Modern Greek. They found that the test is easy and reliable to administer and 
Table 1. Frequency of occurrence of phonemes in Modern Greek spoken language (Trimmis, 2006) and frequency of nonsense lists 1 and 2.

\begin{tabular}{|c|c|c|c|c|}
\hline & $\begin{array}{l}\text { Phonemes } \\
\text { IPA Symbol }\end{array}$ & $\begin{array}{c}\text { Frequency } \\
\text { Everyday speech } \\
(\%)\end{array}$ & $\begin{array}{l}\text { List } 1 \\
\text { Frequency } \\
(\%)\end{array}$ & $\begin{array}{c}\text { List } 2 \\
\text { Frequency } \\
(\%)\end{array}$ \\
\hline 1 & a & 12.26 & 11.71 & 11.71 \\
\hline 2 & e & 10.40 & 9.91 & 9.91 \\
\hline 3 & i & 14.25 & 13.51 & 13.51 \\
\hline 4 & 0 & 9.49 & 8.11 & 8.11 \\
\hline 5 & $u$ & 2.50 & 1.80 & 1.80 \\
\hline 6 & $r$ & 4.18 & 3.60 & 3.60 \\
\hline 7 & $\theta$ & 1.11 & 0.90 & 0.90 \\
\hline 8 & д & 2.04 & 1.80 & 1.80 \\
\hline 9 & $b$ & 0.26 & 0.90 & 0.90 \\
\hline 10 & $d$ & 0.54 & 0.90 & 0.90 \\
\hline 11 & ts & 0.11 & 0.90 & 0.90 \\
\hline 12 & tz & 0.02 & 0.90 & 0.90 \\
\hline 13 & $p$ & 4.36 & 4.50 & 4.50 \\
\hline 14 & $\mathrm{~m}$ & 3.69 & 3.60 & 3.60 \\
\hline 15 & f & 1.28 & 0.90 & 0.90 \\
\hline 16 & v & 0.88 & 0.90 & 0.90 \\
\hline 17 & $\mathrm{t}$ & 7.54 & 7.21 & 7.21 \\
\hline 18 & z & 0.54 & 0.90 & 0.90 \\
\hline 19 & s & 7.68 & 7.21 & 7.21 \\
\hline 20 & $n$ & 6.17 & 6.31 & 6.31 \\
\hline 21 & g & 0.12 & 0.90 & 0.90 \\
\hline 22 & 1 & 2.77 & 2.70 & 2.70 \\
\hline 23 & k & 2.62 & 2.70 & 2.70 \\
\hline 24 & $x$ & 0.60 & 0.90 & 0.90 \\
\hline 25 & $r$ & 0.74 & 0.90 & 0.90 \\
\hline 26 & c & 1.79 & 1.80 & 1.80 \\
\hline 27 & ç & 0.88 & 0.90 & 0.90 \\
\hline 28 & j & 0.98 & 0.90 & 0.90 \\
\hline 29 & $\kappa$ & 0.11 & 0.90 & 0.90 \\
\hline 30 & $\eta$ & 0.10 & 0.90 & 0.90 \\
\hline
\end{tabular}

score. However, monosyllables are known to be less redundant when compared to bisyllables or multisyllables (Martin, 1997).

Considering the limited number of materials for performing speech audiological tests in the Modern Greek language for rehabilitative applications, the purpose of the present study was to develop a nonsense monosyllabic suprathreshold speech audiometry test for native speakers of Modern Greek. The specific aims of the present study were to construct phonemically balanced lists of nonsense monosyllables, to digitally record the lists, to perform a preliminary investigation of interlist equivalence on normal hearing subjects, and to compare recognition scores of nonsense monosyllables, nonsense bisyllables, and bisyllabic words. 
Table 2. The two nonsense monosyllabic lists.

\begin{tabular}{|c|c|c|c|c|c|c|c|}
\hline \multicolumn{4}{|c|}{ List 1} & \multicolumn{4}{|c|}{ List 2} \\
\hline IPA & $\begin{array}{l}\text { Modern } \\
\text { Greek }\end{array}$ & IPA & $\begin{array}{c}\text { Modern } \\
\text { Greek }\end{array}$ & IPA & $\begin{array}{l}\text { Modern } \\
\text { Greek }\end{array}$ & IPA & $\begin{array}{c}\text { Modern } \\
\text { Greek }\end{array}$ \\
\hline tas & $\tau \alpha \varsigma$ & pit & $\pi \iota \tau$ & sat & $\sigma \alpha \tau$ & $\mathrm{i} \theta$ & $\imath \theta$ \\
\hline $\tan$ & $\tau \alpha \nu$ & $\theta \mathrm{i}$ & $\theta \mathrm{r}$ & nat & $v \alpha \tau$ & ði & $\delta \mathrm{\imath}$ \\
\hline sa & $\sigma \alpha$ & ip & $1 \pi$ & ra & $\rho \alpha$ & bi & $\mu \pi \imath$ \\
\hline ar & $\alpha \rho$ & Ґ & $1 \delta$ & ка & $\lambda \iota \alpha$ & tsi & $\tau \sigma \iota$ \\
\hline ba & $\mu \pi \alpha$ & di & $v \tau \imath$ & ya & $v i \alpha$ & ik & $1 \kappa$ \\
\hline dza & $\tau \zeta \alpha$ & pim & $\pi \imath \mu$ & ya & $\gamma \alpha$ & il & $\imath \lambda$ \\
\hline $\mathrm{pa}$ & $\pi \alpha$ & if & $1 \phi$ & aк & $\alpha \kappa$ & ig & $\imath \gamma \kappa$ \\
\hline $\mathrm{am}$ & $\alpha \mu$ & nis & vis & nap & $v \alpha \pi$ & sir & $\sigma \iota \rho$ \\
\hline tal & $\tau \alpha \lambda$ & li & $\lambda_{1}$ & $\mathrm{fa}$ & $\varphi \alpha$ & iz & $1 \zeta$ \\
\hline ka & $\kappa \alpha$ & ni & $v \imath$ & va & $\beta \alpha$ & sit & $\sigma \iota \tau$ \\
\hline ay & $\alpha \gamma$ & si & $\sigma l$ & ap & $\alpha \pi$ & nim & $v i \mu$ \\
\hline $\mathrm{ca}$ & $\kappa \alpha$ & gi & $\gamma \kappa 1$ & at & $\alpha \tau$ & it & $1 \tau$ \\
\hline ça & $\chi 1 \alpha$ & vi & $\beta \mathrm{l}$ & nas & $v \alpha \varsigma$ & is & 15 \\
\hline sen & $\sigma \varepsilon v$ & nit & $\nu \imath \tau$ & nes & $v \varepsilon \zeta$ & mip & $\mu 1 \pi$ \\
\hline et & $\varepsilon \tau$ & or & o $\rho$ & er & $\varepsilon \rho$ & ot & $\mathrm{o} \tau$ \\
\hline sem & $\sigma \varepsilon \mu$ & до & 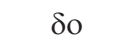 & еð & $\varepsilon \delta$ & $\mathrm{CO}$ & $\kappa о$ \\
\hline je & $\gamma 1 \varepsilon$ & on & ov & de & $\nu \tau \varepsilon$ & ço & $\chi 10$ \\
\hline ze & $\zeta \varepsilon$ & tso & $\tau \sigma o$ & dze & $\tau \zeta \varepsilon$ & jo & $\gamma 10$ \\
\hline let & $\lambda \varepsilon \tau$ & po & $\pi \mathrm{o}$ & el & $\varepsilon \lambda$ & xo & $\chi_{0}$ \\
\hline ek & $\varepsilon \kappa$ & om & $\mathrm{o} \mu$ & pe & $\pi \varepsilon$ & ok & OK \\
\hline ex & $\varepsilon \chi$ & Ko & $\lambda 10$ & ep & $\varepsilon \pi$ & 10 & $\lambda_{0}$ \\
\hline en & $\varepsilon v$ & ko & ко & met & $\mu \varepsilon \tau$ & son & бov \\
\hline es & $\varepsilon \varsigma$ & $\cos$ & Kı০s & te & $\tau \varepsilon$ & so & $\sigma o$ \\
\hline ne & $\nu 1 \varepsilon$ & ut & ou $\tau$ & em & $\varepsilon \mu$ & un & OUV \\
\hline ri & $\rho \imath$ & ru & pov & ir & $1 \rho$ & $\mathrm{cu}$ & KiOU \\
\hline
\end{tabular}

\section{Methodology and Materials}

\section{Development of the lists}

The following criteria were adopted for the selection of list items:

\section{Phonemic balance}

A phonemically balanced list is one in which the occurrence or frequency of the phonemes approximate the spoken language from which the phonemes are derived. The purpose of this balance is to increase the validity of the test for predicting real-life speech perception (Martin et al., 2000). The phonemes appear in the test material with similar relative frequency as that in everyday speech (Table 1). It was impossible to produce a test with the same frequency due to the limited number of phonemes in each list. Each phoneme changes the phonemic balance by $0.90 \%$ (see Table 1). Test lists are regarded as interchangeable if each has the same phonemic balance (Martin et al., 1997).

\section{Phonemic differentiation}

Every syllable in each list should not be easily confused with another syllable in the same list. Therefore, there is a minimum difference of one phoneme between the monosyllables in each list.

\section{Nonsense syllables}

Nonsense syllables with possible CV, VC, and CVC phonemic combinations in Modern Greek were chosen as stimuli (Table 2). All nonsense phonemic combinations were 
Table 3. Means and standard deviations for the two lists per $5 \mathrm{~dB}$ for men, and $t$-tests and $p$-values for the two-sample $t$-test for comparing two means of two independent groups ( $N=20$ for each group).

\begin{tabular}{|c|c|c|c|c|c|c|}
\hline \multirow{2}{*}{ dB HL } & \multicolumn{2}{|c|}{ List 1} & \multicolumn{2}{|c|}{ List 2} & \multicolumn{2}{|c|}{$\begin{array}{l}\text { Two-sample } \\
t \text {-test for mean comparison }\end{array}$} \\
\hline & Mean & $\begin{array}{l}\text { Standard } \\
\text { Deviation }\end{array}$ & Mean & $\begin{array}{l}\text { Standard } \\
\text { Deviation }\end{array}$ & $t$-test & $p$-value \\
\hline 0 & 0.40 & 0.50 & 0.35 & 0.49 & 0.29 & 0.7715 \\
\hline 5 & 2.60 & 2.30 & 2.65 & 2.28 & -0.08 & 0.9350 \\
\hline 10 & 7.95 & 3.62 & 7.50 & 2.74 & 0.47 & 0.6459 \\
\hline 15 & 15.50 & 5.33 & 15.40 & 4.39 & 0.07 & 0.9420 \\
\hline 20 & 25.20 & 7.16 & 25.00 & 5.20 & 0.12 & 0.9024 \\
\hline 25 & 36.40 & 5.77 & 33.95 & 5.34 & 1.72 & 0.1013 \\
\hline 30 & 41.40 & 4.57 & 39.75 & 4.51 & 1.57 & 0.1333 \\
\hline 35 & 45.30 & 2.75 & 44.20 & 2.82 & 1.96 & 0.0649 \\
\hline 40 & 47.15 & 1.79 & 46.75 & 2.10 & 0.78 & 0.4424 \\
\hline 45 & 48.10 & 1.41 & 48.30 & 1.59 & -0.47 & 0.6446 \\
\hline 50 & 49.00 & 0.97 & 48.90 & 1.21 & 0.30 & 0.7663 \\
\hline 55 & 49.35 & 0.99 & 49.50 & 0.89 & -0.55 & 0.5906 \\
\hline 60 & 49.55 & 0.99 & 49.60 & 0.82 & -0.20 & 0.8409 \\
\hline 65 & 49.65 & 0.99 & 49.65 & 0.67 & 0.00 & 1.0000 \\
\hline 70 & 49.75 & 0.64 & 49.65 & 0.67 & 0.57 & 0.5770 \\
\hline 75 & 49.85 & 0.37 & 49.70 & 0.66 & 1.00 & 0.3299 \\
\hline 80 & 49.85 & 0.37 & 49.85 & 0.49 & 0.00 & 1.0000 \\
\hline 85 & 49.85 & 0.37 & 49.85 & 0.49 & 0.00 & 1.0000 \\
\hline 90 & 49.85 & 0.37 & 49.85 & 0.49 & 0.00 & 1.0000 \\
\hline 95 & 49.85 & 0.37 & 49.85 & 0.49 & 0.00 & 1.0000 \\
\hline 100 & 49.85 & 0.37 & 49.90 & 0.31 & -0.57 & 0.5770 \\
\hline
\end{tabular}

selected from a large pool of data for everyday speech represented by a phonemic analysis of 102,934 words obtained from 100 television and radio shows from the national Hellenic broadcasting station (Trimmis et al., 2006). Thus, the content of the lists was representative of the phonemic combinations of Modern Greek spoken language. No one of the syllables selected in the final lists carries a semantic content in Modern Greek.

\section{Recording of material}

\section{Speaker}

Initial recordings were made using 3 female professional speakers. All spoke the standard Modern Greek dialect and the performance of each one of them was evaluated by two native judges (speech therapists) based on standard dialect, articulation, vocal quality, and fluency. Talkers were asked to speak at a natural rate with normal intonation patterns. The highest ranked female speaker was chosen to be the speaker of the final recordings.

\section{Recordings}

All 100 words were recorded in an isolated soundproof booth located at the Technological Institute of Patras campus in the Speech and Hearing clinic which meets ANSI standards for maximum permissible ambient noise levels for uncovered ears (American National Standards Institute, 1999). An AKG model C-1000-S condenser microphone positioned at optimum distance, a FireWire Solo sound card interfaced to a PC computer, and a digital signal processing software (Adobe Audition Version 1) were used for all recording and editing tasks. Each digitised word (sampling frequency 44.100 $\mathrm{kHz}$, single channel, 16-bit resolution) was placed in a unique file for further editing. Each file was edited using Adobe Audition software for noise elimination, for 
Table 4. Means and standard deviations for the two lists per $5 \mathrm{~dB}$ for women, and $t$-tests and $p$-values for the twosample $t$-test for comparing two means of two independent groups ( $N=20$ for each group).

\begin{tabular}{|c|c|c|c|c|c|c|}
\hline \multirow{2}{*}{ dB HL } & \multicolumn{2}{|c|}{ List 1} & \multicolumn{2}{|c|}{ List 2} & \multicolumn{2}{|c|}{$\begin{array}{l}\text { Two-sample } \\
t \text {-test for mean comparison }\end{array}$} \\
\hline & Mean & $\begin{array}{l}\text { Standard } \\
\text { Deviation }\end{array}$ & Mean & $\begin{array}{l}\text { Standard } \\
\text { Deviation }\end{array}$ & $t$-test & $p$-value \\
\hline 0 & 0.30 & 0.57 & 0.20 & 0.41 & 0.70 & 0.4936 \\
\hline 5 & 1.65 & 1.87 & 1.70 & 1.75 & -0.11 & 0.9169 \\
\hline 10 & 7.25 & 3.40 & 8.10 & 3.29 & -0.99 & 0.3366 \\
\hline 15 & 15.75 & 5.79 & 15.20 & 5.42 & 0.54 & 0.5940 \\
\hline 20 & 24.85 & 7.52 & 24.45 & 6.78 & 0.35 & 0.7293 \\
\hline 25 & 32.70 & 9.00 & 32.95 & 8.44 & -0.30 & 0.7707 \\
\hline 30 & 41.10 & 6.63 & 39.90 & 6.68 & 1.37 & 0.1864 \\
\hline 35 & 45.00 & 4.24 & 44.50 & 4.26 & 1.04 & 0.3092 \\
\hline 40 & 46.70 & 2.36 & 47.00 & 2.13 & -0.56 & 0.5840 \\
\hline 45 & 47.95 & 1.73 & 47.95 & 1.85 & 0.00 & 1.0000 \\
\hline 50 & 48.65 & 1.14 & 48.75 & 1.12 & -0.29 & 0.7764 \\
\hline 55 & 48.95 & 1.00 & 49.20 & 0.95 & -0.77 & 0.4490 \\
\hline 60 & 49.15 & 0.88 & 49.45 & 0.83 & -1.00 & 0.3299 \\
\hline 65 & 49.15 & 0.88 & 49.70 & 0.73 & -1.93 & 0.0690 \\
\hline 70 & 49.50 & 0.69 & 49.75 & 0.72 & -1.04 & 0.3092 \\
\hline 75 & 49.55 & 0.69 & 49.75 & 0.72 & -0.81 & 0.4283 \\
\hline 80 & 49.60 & 0.60 & 49.75 & 0.72 & -0.65 & 0.5266 \\
\hline 85 & 49.60 & 0.60 & 49.80 & 0.70 & -0.89 & 0.3847 \\
\hline 90 & 49.65 & 0.58 & 49.80 & 0.70 & -0.68 & 0.5054 \\
\hline 95 & 49.70 & 0.47 & 49.90 & 0.31 & -1.45 & 0.1625 \\
\hline 100 & 49.70 & 0.47 & 49.95 & 0.22 & -2.03 & 0.0563 \\
\hline
\end{tabular}

minimising the silence before and after the stimulus item, and for equalisation.

\section{Interlist equivalence}

\section{Participants}

A total of 40 subjects (20 male and 20 female) participated in evaluating the nonsense monosyllabic combinations. All participants (average age 26.2 years; SD 1.89) were monolingual native speakers of Modern Greek and had no reported histories of otologic or speech and language problems. All exhibited pure tone air-conduction and bone-conduction thresholds of $\leq 15 \mathrm{~dB} \mathrm{HL}$ at octave frequencies from $250 \mathrm{~Hz}$ through $8000 \mathrm{~Hz}$ and static acoustic admittance between 0.3 and 1.4 mmhos with peak pressure between -20 and $+40 \mathrm{daPa}$ (ASHA, 1990). Their speech reception thresholds were $\leq 20 \mathrm{~dB}$ HL. All Participants volunteered to take part in this study and were not financially compensated for their participation.

\section{Procedure}

Custom software was used to randomly regroup the monosyllables in each list for presentation to the next level or subject. One list was presented at each hearing level.

All testing was done in a soundproof chamber that exceeded standards for ambient noise level for audiometric rooms. The signal was routed from a PC to the external input of an Orbiter 2000 clinical audiometer. The stimuli were routed from the audiometer to the subject via supraaural TDH-49 headphones. Prior to testing each subject, the inputs to the audiometer were calibrated to $0 \mathrm{VU}$ using the $1 \mathrm{kHz}$ calibration tone. Each list was presented monaurally (right ear) starting at $0 \mathrm{~dB} \mathrm{HL}$ and ascending in $5 \mathrm{dBHL}$ steps. The subjects were not familiarised with the monosyllables prior to testing. Prior to administration of the nonsense lists, appropriate instructions were given to the participants. 
Table 5. Means and standard deviations for men and women per $5 \mathrm{~dB}$ for both lists together, and $t$-tests and $p$-values for the two-sample $t$-test for comparing two means of two independent groups (men versus women, $N=20$ for each group).

\begin{tabular}{|c|c|c|c|c|c|c|}
\hline \multirow{2}{*}{ dB HL } & \multicolumn{2}{|c|}{ Men } & \multicolumn{2}{|c|}{ Women } & \multicolumn{2}{|c|}{$\begin{array}{l}\text { Two-sample } \\
t \text {-test for mean comparison }\end{array}$} \\
\hline & Mean & $\begin{array}{l}\text { Standard } \\
\text { Deviation }\end{array}$ & Mean & $\begin{array}{l}\text { Standard } \\
\text { Deviation }\end{array}$ & $t$-test & $p$-value \\
\hline 0 & 0.38 & 0.49 & 0.25 & 0.49 & 1.14 & 0.2593 \\
\hline 5 & 2.63 & 2.26 & 1.68 & 1.79 & 2.08 & 0.0404 \\
\hline 10 & 7.73 & 3.18 & 7.68 & 3.33 & 0.07 & 0.9454 \\
\hline 15 & 15.45 & 4.82 & 15.48 & 5.54 & -0.02 & 0.9829 \\
\hline 20 & 25.10 & 6.18 & 24.65 & 7.07 & 0.30 & 0.7626 \\
\hline 25 & 35.17 & 5.63 & 32.83 & 8.61 & 1.44 & 0.1532 \\
\hline 30 & 40.58 & 4.56 & 40.50 & 6.60 & 0.06 & 0.9530 \\
\hline 35 & 44.75 & 2.81 & 44.75 & 4.20 & 0.00 & 1.0000 \\
\hline 40 & 46.95 & 1.93 & 46.85 & 2.22 & 0.21 & 0.8307 \\
\hline 45 & 48.20 & 1.49 & 47.95 & 1.77 & 0.68 & 0.4960 \\
\hline 50 & 48.95 & 1.08 & 48.70 & 1.11 & 1.02 & 0.3124 \\
\hline 55 & 49.43 & 0.93 & 49.08 & 0.97 & 1.65 & 0.1038 \\
\hline 60 & 49.58 & 0.90 & 49.30 & 0.85 & 1.12 & 0.7276 \\
\hline 65 & 49.65 & 0.83 & 49.43 & 0.84 & 1.02 & 0.9392 \\
\hline 70 & 49.70 & 0.65 & 49.63 & 0.70 & 1.18 & 0.6052 \\
\hline 75 & 49.78 & 0.53 & 49.65 & 0.70 & 1.74 & 0.0876 \\
\hline 80 & 49.85 & 0.43 & 49.68 & 0.66 & 2.36 & 0.0086 \\
\hline 85 & 49.85 & 0.43 & 49.70 & 0.65 & 2.31 & 0.0104 \\
\hline 90 & 49.85 & 0.43 & 49.73 & 0.64 & 2.25 & 0.0130 \\
\hline 95 & 49.85 & 0.43 & 49.80 & 0.41 & 1.11 & 0.7475 \\
\hline 100 & 49.88 & 0.33 & 49.82 & 0.38 & 1.32 & 0.3898 \\
\hline
\end{tabular}

\section{Results}

Two lists of nonsense material were developed, each containing 50 items with possible $\mathrm{CV}, \mathrm{VC}$, and CVC combinations (Table 2). The lists satisfied the criteria of equal phonemic balance, composition of Modern Greek speech, phonemic differentiation, and equal average difficulty. Statistical analysis of the results was performed by executing $t$-tests for every hearing level.

Statistical analysis of the men in our sample revealed that there were no statistically significant differences $(p<0.05)$ in their performances on List I and List II, as shown in Table 3.

The statistical analysis of the women in our sample revealed that there were no statistically significant differences $(p<0.05)$ in their performances on List I and List II, as shown in Table 4.
The statistical analysis for both List I and List II together revealed that there were some statistically significant differences $(p<0.05)$ between men and women, as shown in Table 5. The differences appear at the 5, 80, 85, and $90 \mathrm{~dB}$ hearing levels (dB HL).

Comparison of recognition scores for the different type of speech stimulus is displayed in Figure 1. It can be seen, as expected, that the bisyllabic word recognition curve is steeper than with nonsense material.

\section{Discussion}

No more than two lists with 50 nonsense monosyllables were able to be developed due to the criterion of phonemic differentiation and the limited number of possible phonemes and phonemic combinations. All monosyllables selected were low in redundancy, thus keeping the number of phonemes as low as possible. Phonemes are 


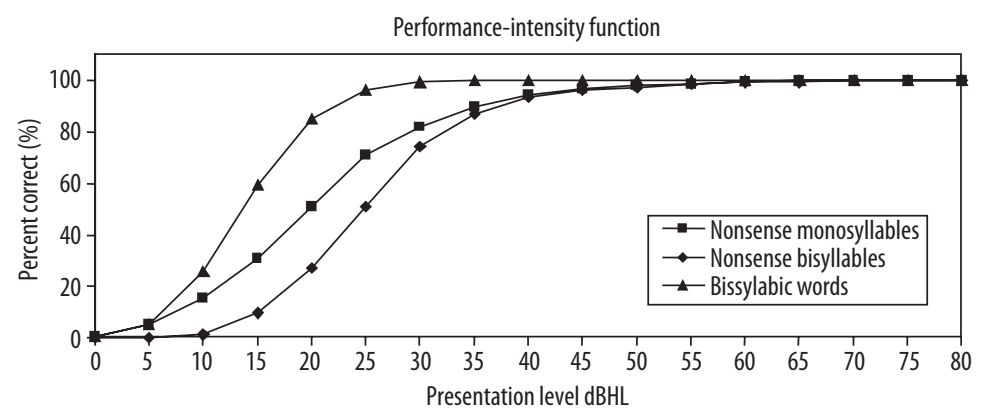

Figure 1. Monaural mean percent correct recognition scores for each type of stimulus (nonsense monosyllables, nonsense bisyllables, bisyllabic words).

the least and sentences the most redundant type of item. Intelligibility curves suggest that the higher the redundancy, the fewer the acoustic cues needed to recognise a stimulus (Martin et al., 1997). Each list contains only 111 phonemes, making it possible to test outcomes based on phonemic scoring and therefore reducing variability of test scores based on the binomial model and increasing reliability of the test (Raffin \& Schafer, 1980; Raffin \& Thornton, 1980; Thornton \& Raffin, 1978).

Results showed that there were no statistical significant differences between the two lists for both men and women with normal hearing (Tables 3 and 4). However, differences at the 0.05 level were found between men and women for both lists at 5, 80, 85, and $90 \mathrm{~dB}$ HL (Table 5). It can be argued that these findings are probably due to the small number of participants and suggest that further investigation is required with larger number of subjects with normal hearing and different types and degrees of hearing loss. This will lead to an assessment of the reliability and validity of the lists.

In the present study, the test was presented to listeners in quiet and patients responded in an open-set format. However, in future studies, the test can also be presented in noise at different signal-to-noise ratios (SNRs), and in a low-pass filter condition with different cut-off frequencies. In addition, a closed-set format can also be used for special situations when an open-set format is not applicable, such as in the case of geriatric patients with memory difficulties or children.

The nonsense monosyllables and nonsense bisyllables (Trimmis et al., 2009) were found to result in significantly poorer recognition scores than the bisyllabic words with semantic content (Trimmis et al., 2006). These findings are similar to those noted in previous studies (Kirk et al., 2000;
Jamieson, 2004; Zakrzewski, 1975; Woods et al., 2010). However, an interesting finding is that nonsense monosyllables revealed steeper functions than the nonsense bisyllables (Figure 1), which is in contrast with speech stimuli that carries semantic content. The more phonemes and the more acoustic redundancy that characterise a word, the more easily it is recognised (Martin et al., 1997).

Although nonsense material has not been widely used in clinical evaluation of hearing impaired patients due to the complexity involved in scoring the subject's responses and the difficulty an untrained listener may have in repeating nonlinguistic stimuli (Martin et al., 1997), a strong correlation was found between the number of NST errors and hearing loss (Butts et al., 1987). Also, excellent predictive relationships were found between total NST errors and a weighted pure-tone average for slight to marked sensorineural hearing loss (Butts et al., 1987).

The results of the present study demonstrate that this nonsense monosyllabic test appears to be a useful additional tool for clinical purposes in the areas of aural rehabilitation since improved speech recognition remains the primary goal of hearing aid selection. In addition, all rehabilitative programs contain phoneme recognition training. If future results demonstrate sufficient reliability and validity, then the test can be used by both the clinical and research audiologist for evaluation of new training techniques and devices within the scope of rehabilitation.

\section{Conclusions}

Phonemically balanced lists of nonsense monosyllables have been constructed and preliminary investigation of the lists have confirmed their equivalence. Future research to prove clinical usefulness is planned.

\section{References:}

1. Martin F, Armstrong T, Champlin C: A survey of audiological practices in the United States. Am J Audiol, 1994; 3: 20-26

2. American Speech-Language Hearing Association. Guidelines for determining threshold level for speech. ASHA, 1988; 30: 85-89

3. Carhart R: Basic principles of speech audiometry. Acta Otolaryngol, 1951; 40: 62-71
4. Trimmis N, Papadeas E, Papadas T et al: Speech Audiometry: The Development of Modern Greek Word Lists for Suprathreshold Word Recognition Testing. The Mediterranean Journal of Otology, 2006; 2(3): 117-26

5. Iliadou V, Fourakis M, Vakalos A et al: Bi-syllabic, Modern Greek word lists for use in word recognition tests. Int J Audiol, 2006; 45: 74-82

6. Brad AS: Clinical Audiology-An Introduction. $2^{\text {nd }}$ ed. New York, USA: Delmar, Cengage Learning; 2010 
7. Martin M (ed.): Speech audiometry. $2^{\text {nd }}$ ed. London, England: Whurr Publishers Ltd.; 1997

8. Gelfand SA: Essentials of Audiology. New York: Thieme Medical, 2001

9. Resnick SB, Dubno JR, Hoffnung $S$ et al: Phoneme errors in a nonsense syllable test. J Acoust Soc Am, 1975; 58(Suppl.1): S114(A)

10. Levitt H, Resnick SB: Speech reception by the hearing impaired: methods of testing and the development of new tests. Scandinavian Audiology, 1978; (Suppl.6): 107-130

11. Edgerton BJ, Danhauer JL: Clinical Implication of Speech Discrimination Testing Using Nonsense Stimuli. Baltimore: University Park Press, 1979

12. Kuk F, Lau CC, Korhonen P et al: Development of the ORCA Nonsense Syllable Test. Ear and Hearing, 2010; 31(6): 779-95

13. Trimmis N, Markatos N, Malaperdas K, Papadas T: Development of an Audio Compact Disc for Speech Audiometry Testing. Proceedings of the $8^{\text {th }}$ EFAS Congress: Joint meeting with the $10^{\text {th }}$ Congress of the German Society of Audiology; 2007 June 6-9; Heidelberg, Germany. Oldenburg: German Society of Audiology; 2008

14. Trimmis N, Papadeas E, Papadas T et al: A Modern Greek Word Recognition Score Test Designed for School Aged Children. The Mediterranean Journal of Otology, 2008; 4(1): 1-8

15. Thrasyvoulou G, Marinakis K: Speech Audiometry in everyday practice. Hellenic Otorhinolaryngology-Head an Neck Surgery, 2010; 2: 101-4

16. Trimmis N, Makri V, Markatos N, Gouma P: Development of a nonsense speech recognition test in Modern Greek. Proceedings of the $9^{\text {th }}$ EFAS Congress: Joint meeting with the VI Congress of the Spanish Society of Audiology, 2009 June 21-24; Canary Islands, Spain
17. Martin FN, Champlin CA, Perez DD: The question of phonetic balance in word recognition testing. J Am Acad Audiol, 2009; 11: 489-94

18. American National Standards Institute. Maximum permissible ambient noise levels for audiometric test rooms. New York: ANSI, 1999

19. Raffin MJ, Schafer D: Application of a probability model based on the binomial distribution to speech-discrimination scores. J Speech Hear Res, 1980; 23: 570-75

20. Raffin MJ, Thornton A: Confidence levels for differences between speech discrimination scores. J Speech Hear Res, 1980; 23: $5-18$

21. Thornton A, Raffin MJ: Speech discrimination scores modeled as a binomial variable. J Speech Hear Res, 1978; 21: 507-18

22. Kirk KI, Hay-McCutcheon M, Sehgal ST, Miyamoto RT: Speech perception in children with cochlear implants: effects of lexical difficulty, talker variability, and word length. Ann Otol Rhinol Laryngol Suppl, 2000; 185: 79-81

23. Jamieson DG, Kranjc G, Yu K et al: Speech intelligibility of young school-aged children in the presence of real-life classroom noise. J Am Acad Audiol, 2004; 15(7): 508-17

24. Zakrzewski A, Jassem W, Pruszewicz A, Obrebowski A: Identification and Discrimination of Speech Sounds in Monosyllabic Meaningful Words and Nonsense Words by Children. Int J Audiol, 1975; 14(1): 21-26

25. Woods DL, Yund EW, Herron TJ: Measuring consonant identification in nonsense syllables, words, and sentences. J Rehabil Res Dev, 2010; 47(3): 243-60

26. Butts FM, Ruth RR, Schoeny ZG: Nonsense Syllable Test (NST)Results and Hearing Loss. Ear and Hearing, 1987; 8(1): 44-48 